UDC 331

DOI: https://doi.org/10.32840/2522-4263/2020-3-11

\author{
Nikitina Alina \\ Candidate of Economic Sciences, Associate Professor, \\ Associate Professor of International Economics and FEA management, \\ Simon Kuznets Kharkiv National University of Economics
}

Klymenko Anna, Nevzorova Olga

Students

Simon Kuznets Kharkiv National University of Economics

Нікітіна А.В.

кандидат еконолічних наук, доцент, доцент кафедри міжнародної еконоліки та менеджменту ЗЕД Харківського національного еконолічного університету ілені Селена Кузнеия

Клименко А.С., Невзорова О.В. студентки

Харківського національного еконолічного університету ілені Селена Кузнеця

\title{
ANALYSIS OF THE IMPACT OF THE CORONAVIRUS PANDEMIC ON THE GLOBAL ECONOMY: CONSEQUENCES, RISKS AND FORECASTS
}

\section{АНАЛІЗ ВПЛИВУ ПАНДЕМІЇ КОРОНАВІРУСУ НА СВІТОВУ ЕКОНОМІКУ: НАСЛІДКИ, РИЗИКИ ТА ПРОГНОЗИ}

\section{ANNOTATION}

The paper highlights the impact of the COVID-19 virus and quarantine measures on the economic and political situation in the world. The analysis of preventive measures on virus spreading was conducted. The methods of prevention of negative consequences for the state economy and provision of social guarantees for the population are considered. And also the most probable and most significant risks caused in its turn by the pandemic itself, by the way the government and world organizations reacted to the appeared danger and, first of all, by the reaction of the population to the specified instructions from the ruling bodies of the countries as it is known that the greatest risk of virus infection is the so-called method "from neighbor to neighbor», exactly by this fact quarantine was introduced in the majority of countries, and the borders of the states were closed, as well as those caused by the measures aimed at support of the population and small population. The study assessed the forecasts of political and economic experts regarding further economic development. Also, this paper offered their own vision of the global economic situation caused by the spread of respiratory infections.

Key words: coronavirus, impact of pandemic, consequences, world economy, risks, forecasts, economic and political situation, pandemic COVID-19.

\section{АНОТАЦІЯ}

Швидке поширення інфекції коронавірусу COVID-19 нині викликає серйозні проблеми у сфері охорони здоров'я в усьому світі. Інфекція має не лише гуманітарні, а й значні комерційні наслідки у світовому масштабі. Новий тип коронавірусної пандемії вже мав надзвичайно сильний вплив (навіть порівняно з також досить небезпечною ГРВІ) на світову економіку, що, звісно, починає впливати на економіку окремих країн. Негативні економічні наслідки, ймовірно, будуть досить тривалими. Важко передбачити вплив пандемії на світову економічну та політичну ситуацію, саме тому важливо вивчити питання, події, які вже відбулися, та передбачити можливі наслідки. У роботі висвітлено вплив поширення коронавірусу та карантинних заходів на економічну та політичну ситуацію окремих країн та світу в цілому. Досить тривалі карантинні заходи в усьому світі призведуть до значних економічних утрат як усередині країн, так і на міжнародному ринку. Також важким для політики та економіки буде процес виходу з карантину. Для полегшення перебігу цих подій уряди багатьох країн розробляють окремі етапи виходу зі стану карантину. У статті проведено аналіз превентивних заходів щодо поширення інфекції коронавірусу. Розглянуто різноманітні методи попередження негативних наслідків для економіки держави та забезпечення соціальних гарантій для населення. Мали місце також заходи, що були спрямовані на моральну підтримку населення та запобігання розповсюдженню не тільки інфекції, а й панічних настроїв. Виокремлено можливі ризики, викликані заходами, спрямованими на підтримку населення країни та бізнесу. Загалом ситуація дуже мінлива і постійно змінюється. Уряди держав щодня вирішують, як протистояти кризі з найменшими втратами та як їх рішення можуть вплинути на довгострокову перспективу. У зв'язку із цим у роботі проаналізовано основні події останніх місяців, які $€$ найбільш значущими і достатньо відображають загальний актуальний настрій провідних країн та їхню реакцію на події. Здебільшого розглянуто ті країни, які вживають найзначніших заходів і все ж мають найбільші втрати через пандемію. До них належать країни Європи, США. У ході дослідження було також оцінено прогнози експертів щодо подальшого економічного розвитку. Запропоновано власне бачення економічної ситуації у світі, спричиненої поширенням коронавірусу.

Ключові слова: коронавірус, вплив пандемії, наслідки, світова економіка, ризики, прогнози, економічна та політична ситуація, пандемія COVID-19.

\section{АННОТАЦИЯ}

В работе освещено влияние распространения вируса COVID-19 и карантинных мер на экономическую и политическую ситуацию в мире. Проведен анализ превентивных мер по распространению вируса. Рассмотрены методы предупреждения негативных последствий для экономики государства и обеспечения социальных гарантий для населения. Выделены самые вероятные и наиболее значимые риски, вызванные непосредственно самой пандемией, тем, как правительство и всемирные организации реагировали на возникшую опасность и, прежде всего, реакцией населения на инструкции от правящих органов стран. Как известно, наибольший риск заражения вирусом - так называемый способ «от соседа к соседу», именно поэтому в большинстве стран был введен карантин, а границы государств были закрыты. В ходе исследования также оценены прогнозы политических и экономических экспертов 
относительно дальнейшего экономического развития. Предложено собственное видение экономической ситуации в мире, вызванной распространением пандемии.

Ключевые слова: коронавирус, влияние пандемии, последствия, мировая экономика, риски, прогнозы, экономическая и политическая ситуация, пандемия COVID-19.

Introduction. The rapid spread of coronavirus raises serious public health concerns. Infection has not only humanitarian but also significant commercial consequences on a global scale. The new type of coronavirus epidemic has already had an unusually strong impact (even compared to the much more dangerous SARS) on the world economy, which is already beginning to affect the economies of individual countries. Negative economic consequences are likely to be quite long lasting. It is difficult to predict the impact of the pandemic on the world economic and political situation, which is why it is important to study the issue, the events that have already occurred and to predict the possible consequences.

Analysis of recent research. The study was based on the opinions and work of such scientists and experts: Dr. Arturo Casadevall from the Johns Hopkins School of Public Health, virologist from the University of Texas at Galveston Vinit D. Menaheri, a microbiologist from the Ikan School of Medicine in New York Florian Krammer, Dr. Krammer, New York Governor Andrew Cuomo, Stephen Walt - Professor of International Relations at Harvard University, Robin Niblette - Director of the British Royal Institute of International Affairs and others.

Aim of the article. Analyzed measures to counteract the spread of the virus, methods to prevent negative economic consequences. To consider possible risks caused by measures directed on support of the population and business, forecasts concerning the further economic development and to offer the vision of economic situation in the world.

Results. On 31 December 2019, the WHO China Insurance Office was informed of cases of pneumonia for an unknown cause in Wuhan City, Hubei Province, China. Between 31 December 2019 and 3 January 2020, 44 cases of pneumonia with unknown etiology were reported to WHO by Chinese national authorities. Chinese authorities identified a new type of COVID-19 that was isolated on 7 January 2020. In the future the number of cases is only increasing [7]. On 30 January, at a meeting of the WHO Emergency Committee, an outbreak of new COVID-19 was declared a public health emergency of international concern, and on 11 March 2020 WHO announced that the outbreak had become a pandemic, with Europe at its center on 13 March [6].

The pandemic led to business closures in countries with high disease rates, a sharp increase in demand for everyday products and speculation in the market for certain products: antivirals, masks and disinfectants.

Despite the fact that the first COVID-19 outbreak was discovered in China; it is now also of- ten referred to as the «factory of the world» due to the significant world production that is taking place there. But due to the global emergency caused by the pandemic, shipping companies importing goods from China to other countries around the world have been forced to reduce the number of ships in operation due to reduced demand, and in some cases have been unable to access ports due to production stoppages.

The Chinese economy was the first to stop the spread of coronavirus, but as it spread to Europe and the Americas, countries around the world were taking strong measures to contain it. Businesses and offices have been closed and citizens are chained to their homes. Normal economic activity in peacetime was interrupted on an unprecedented scale as daily life patterns changed. Governments were intervening to try to prevent the collapse of companies and livelihoods. China's slowdown due to the coronavirus outbreak was clear and significant for the world economy. Using the financial database Wind, the Financial Times developed a weighted index of six daily industry data series. The domestic economy measures include real estate sales, urban traffic congestion and coal consumption at large power plants. Trade activities are represented by container transportation. The other two indices, which were given less weight, provide a social and environmental context: box office receipts in Chinese cinemas - a good indicator of consumer activity - and air pollution in the 10 largest cities. Overall, China's economic activity index has plummeted since the outbreak of the infection in Wuhan in January 2020. After some time at a low but stable level, the index rose slightly. However, the value remains well below the level of 2019.

In China, services such as entertainment, hotels and catering have been the hardest hit. These effects have been observed in both the USA and Europe. Governments and businesses are responding to the virus in Europe, the retail and hospitality sector is facing a sharp drop in demand as it is closed in many countries. The loss of holidays, events and meals - and the cost of cancellations and refunds - will be difficult for the sector to recover as soon as recovery begins [5].

According to OpenTable, an online restaurant booking service in San Francisco, global demand for restaurants has stopped. Booking for seated diners (\% change on the same day of the year before) fell very sharply after March 9, 2020 in many countries such as Canada, Germany, Ireland and others. The figure is a little higher only in Australia. It recorded almost complete stoppages in all major countries, including the United Kingdom and the United States. Observers began to stay away from restaurants even before the government bans came into effect, as figures show [11].

European new car sales plunge by $51.8 \%$ in March due to coronavirus. BERLIN (Reuters) Passenger car sales tumbled by more than 50\% in Europe's major markets in March as lockdowns 
imposed due to the new coronavirus took their toll, data showed on Friday.

In March, new car registrations dropped by $51.8 \%$ to 853,077 vehicles in the European Union, Britain and the European Free Trade Association countries, statistics from the European Auto Industry Association showed.

Sales fell in all EU markets, with Italy - hit particularly hard by the pandemic - reporting the biggest drop of $85.4 \%$, while registrations tumbled by $37.7 \%$ in Germany, $72.2 \%$ in France and $69.3 \%$ in Spain.

Volkswagen Group's sales decreased by $43.6 \%$ in March, while Renault and PSA Group posted a drop of $63.7 \%$ and $66.9 \%$, respectively.

Sales of cars made by BMW, which was among the few automakers reporting an increase in European sales in the previous months, dropped by $39.7 \%$, while demand for rival Daimler decreased by $40.6 \%$. The decline in registrations comes as the majority of car dealerships in Europe were closed during the second half of March as part of the measures to contain the pandemic. Volkswagen withdrew its 2020 guidance due to uncertainty related to the new coronavirus outbreak which caused operating profit to drop $81 \%$ in the first quarter [1].

Energy consumption, which is a broad indicator of economic activity and is declining in most European countries. In Europe, the decline in electricity consumption was first seen in northern Italy, where it fell by $15 \%$ on March 18 compared to the same day of the week in mid-February. China has seen some recovery from the peak of the crisis, but coal consumption in power plants is still 30 per cent lower than at the beginning of the year. Demand is also expected to decline further around the world as restrictions are becoming more and more common [12].

According to Flightradar24, the number of daily flights worldwide for the seven days to 21 March decreased by more than 20 per cent compared to the same period the previous month, reflecting the collapse of travel and tourism due to the pandemic. Global flight numbers (flight per day) as well as other indicators have fallen sharply. In about 10 days (after March 9, 2020) the number of flights fell by more than $20 \%$. The conditions of increasing travel restrictions in all major economies could lead to a travel and tourism crisis. Given that most countries have closed their borders indefinitely, and in the status quo, any flight is linked either to the transportation of necessary medical equipment, humanitarian assistance, return of remaining citizens to their home countries, or possible prisoner exchange. No tourism is planned for the near future, and at best by the end of summer 2020. This will particularly affect countries that depend on tourism [13].

Due to the shutdown of enterprises in China, and then worldwide, the demand for oil and petroleum products has fallen significantly. Against the backdrop of falling demand between Russia and
OPEC, a price war on the hydrocarbon market began, which in turn led to the collapse of oil prices.

The active spread of the infection around the world also caused the stock market to collapse, which began in mid-February 2020. On March 9, all three NYSE indices fell by more than $7 \%$, and most world markets reported contractions, mainly in response to the 2019-2020 COVID-19 pandemic and the war on oil prices between Russia and Saudi Arabia. On March 12, stocks across Europe and North America fell by more than 9 percent, experiencing the biggest single day drop since black Monday in 1987. Bond prices also fell sharply amidst the unrest, while gold - usually reliable for investors - fell in price [8].

As markets got off balance, expectations rose that policymakers would intervene and start taking stimulus measures to secure global growth for example, by lowering interest rates as a means of potentially boosting lending and consumer activity. Central banks, including in the United States and Australia, moved quickly to reduce related interest rates - in the case of Australia, bringing their benchmark lending rate to a record low level. The G7 meeting held in early March demonstrated the sensitivity of financial markets to turns in response to COVID-19.

Due to this speed of spread and the level of threat of the virus, governments of many countries have taken certain measures to prevent the spread of the disease (such as closing borders, quarantine, etc.). Of course, this will have a number of consequences both for the economies of individual countries and for the world economy as a whole.

Initially, many mass events were cancelled or postponed. Sports competitions, including the Summer Olympic Games in 2020, which were to begin on July 24 in Tokyo, national championships of European countries in almost all sports, including football. Many festivals, exhibitions and competitions were cancelled or postponed, including the Moscow International Film Festival, Cannes Film Festival, Farnborough Airshow and Eurovision 2020 Song Contest. People wishing to attend events have long planned their trips, especially if it was necessary to fly to another country. Obviously, a huge amount of money was allocated for the organization as well, but no one will return the money to the people who wanted to go or to the organizers. For host countries, continental or global events are very lucrative because of the mass influx of tourists, which will no longer exist [3].

Many governments of hundreds of countries and territories with confirmed cases of the COVID-19 pandemic have sought to mitigate its impact at a relatively early stage. South Korea, for example, was able to test for COVID-19 on short notice for a large part of its population, and authorities there have actively sought to implement a tracking regime to identify and isolate those most at risk. 
European governments responded quickly to the crisis. The President of the European Commission has allowed EU bonds or "corona bonds" to be issued to combat the economic impact of the COVID-19 outbreak. Meanwhile, various governments are developing national support programmes.

In France, the government is ready to save business in the epidemic. The French government's measures include deferring all tax and social payments. The minister noted that in the future these payments may be cancelled for those who will face bankruptcy. In addition, the country's authorities intend to provide state guarantees for loans to small and medium-sized enterprises and other measures to help the population and business.

Germany will mobilize at least $€ 500$ billion in loan guarantees. The country will also make it easier for companies to access loans from the state development bank and delay tax payments for companies in difficulty.

The Austrian government has announced an economic assistance package to guarantee companies and provide jobs. The allocated funds will be used to stabilize health care, stimulate the labour market, support public order and reduce income losses caused by the COVID-19 pandemic.

The Polish government has announced a large economic and business assistance package. It is estimated to amount to about PLN 212 billion (\$52 billion). This includes protecting workers from job losses, supporting health care, financial system security, supporting entrepreneurs and public investment. Poland will cover $40 \%$ of company employees' salaries. Employees will also be allowed to withhold social security payments.

In the USA, the Presidential Administration has instructed the Small Business Administration to lend to companies affected by COVID-19. It has been called upon to increase funding for the credit program.

It is also planned to postpone tax payments for individuals and businesses that are negatively affected by the virus outbreak - this will provide more than $\$ 200$ million in additional liquidity for the economy. In addition, no interest will be charged on university loans during the epidemic [10].

One of the measures taken in response to the COVID-19 pandemic has been to help households and small firms, for example by waiving social security contributions, utility bills and channelling loans through financial institutions. The authorities have provided subsidized credit to support increased production of medical equipment and other important activities related to the response to the outbreak.

But such support from the government could have unintended consequences. For example, providing additional time to debtors to meet their financial obligations can undermine financial sustainability; the subsidized loan can be misallocated; and keeping non-viable firms alive can later constrain productivity growth.
Even though there are encouraging signs of economic normalization in China (most large firms report resuming operations and many employees return to their jobs), serious risks remain. For instance, as more and more countries face outbreaks and global financial markets begin to fluctuate, consumers and firms may remain cautious, reducing global demand for Chinese goods. Chinese policymakers should therefore take this into account. Despite the global nature of the outbreak, many of these efforts will be most effective if coordinated internationally [4].

If large-scale outbreaks occur in all countries where cases have been reported, including the United States, India, the United Kingdom, Canada and Brazil, it will mean that growth in all ten of the world's largest economies will slow as they abandon their efforts to fight the spread of the virus. In this case, the growth scenario of the global economy in 2020 will fall to $1.2 \%$, the Eurozone and Japan will fall into recession, and the growth of the American economy will fall to $0.5 \%$.

In another scenario, the most negative scenario is considered. In case of a global pandemic, i.e. when the virus affects all countries, the world economy, according to their forecast, may lose up to $\$ 2.7$ trillion. In this scenario, the growth of the global economy in 2020 may slow down twice, falling by 1.5 p.p. to $1.4-1.5 \%$.

If the outbreak is localized, the growth of the global economy will slow down to $2.4 \%-2.8 \%$ (also due to the slowdown of the Chinese economy).

In any case, 2020 could be the worst year for the world economy since the global economic crisis ended in 2009.

COVID-19 will also accelerate the strengthening of the East and the weakening of the West. South Korea and Singapore coped best with the epidemic and China also did well, after some initial mistakes. At the same time, the measures taken in Europe and America were haphazard and delayed, which will further damage the image of the West [2].

The COVID-19 pandemic will not fundamentally change global economic trends. It will only accelerate the changes that have already begun: the transition from Washington-led globalization to a more Beijing-centric globalization.

Conclusion. Situation is very volatile and changing literally from day to day: politicians and heads of state decide every day how to handle the crisis with the least loss, setting priorities: human lives, security and the economic situation and how their decisions can affect the long term. In this regard, we analyzed the main events of recent months, which, in our view, are the most significant and sufficiently reflect the overall topical mood of the leading countries and their reaction to the events in the status quo. For the most part, we considered those countries that are taking the most significant measures and yet have the largest losses due to the pandemic, which in turn include countries in Europe, the United States. 
In general, overcome the crisis will be main goals of the whole global economy of nearest years. For example, Europe will need around $€ 1.6$ trillion to overcome the crisis. So we can conclude that European Union economy may greatly shrink in 2020. Concerning USA, decline in second quarter gross domestic could be the biggest ever posted.

Also global hunger could become the next big impact of the pandemic. About 265 million people around the world are UN forecasts to be facing acute food insecurity by the end of this year unless swift action is taken to provide food and humanitarian relief to the most at-risk regions. This is twice as much as last year.

Therefore, we can conclude that because of the pandemic, the global economy and politics faced many problems and dire consequences. Such as a decrease in the general level of economic activity, problems in financial markets, possible unemployment and many others. All this can be overcome by establishing international relations while jointly combating the pandemic and its consequences, but this will take a lot of time.

\section{REFERENCES:}

1. Our Standards:The Thomson Reuters Trust Principles [Electronic resource]. Access mode: https://www.reuters.com/companies (accessed 27 March 2020).

2. How does coronavirus affect the economy? World Economic Forum: [Electronic resource]. Access mode: www.weforum.org (accessed 27 March 2020).
3. Strategic insights and contextual intelligence from the World Economic Forum [Electronic resource]. Access mode: https://intelligence.weforum.org/ (accessed 27 March 2020).

4. Coronavirus: OECD warns economic hit will be felt for a long time [Electronic resource]. Access mode: https://www.cnbc. com (accessed 2 April 2020).

5. Coronavirus' business impact: Evolving perspective | McKinsey [Electronic resource]. Access mode: https://www.mckinsey.com/business-functions/risk/our-insights/covid-19-implications-for-business (accessed 2 April 2020).

6. Coronavirus disease (COVID-19) Pandemic | World Health Organization [Electronic resource]. Access mode: https://www. who.int/emergencies/diseases/novel-coronavirus-2019 (accessed 27 March 2020)

7. Coronavirus disease (COVID-2019) situation reports | World Health Organization [Electronic resource]. Access mode: https://www.who.int/emergencies/diseases/novel-coronavirus-2019/situation-reports/ (accessed 27 March 2020).

8. ProFinance service: online trading [Electronic resource]. Access mode: http://www.profinance.ru/chart/brent/ (accessed 2 April 2020)

9. Coronavirus global health emergency | United Nations [Electronic resource]. Access mode: https://www.un.org/en/coronavirus (accessed 27 March 2020).

10. OpenTable: Restaurants and Restaurant Reservations [Electronic resource]. Access mode: https://www.opentable.com/ (accessed 23 March 2020).

11. Financial Time [Electronic resource]. Access mode: https://www.ft.com/ (accessed 23 March 2020)

12. Flightradar24 Access mode: https://www.flightradar24.com/ (accessed 20 March 2020). 